\title{
Short-term temporal and spatial dynamics of bacterioplankton near Barbados in the Caribbean Sea
}

\author{
Keun-Hyung Choi ${ }^{1, *}$, Fred C. Dobbs ${ }^{1}$, Robert K. Cowen ${ }^{2}$ \\ ${ }^{1}$ Department of Ocean, Earth and Atmospheric Sciences, Old Dominion University, 4600 Elkhorn Ave, Norfolk, \\ Virginia 23529, USA \\ ${ }^{2}$ Division of Marine Biology and Fisheries, Rosenstiel School of Marine and Atmospheric Science, University of Miami, \\ Miami, Florida 33149, USA
}

\begin{abstract}
To investigate temporal (ca $1 \mathrm{mo}$ ) and spatial dynamics of bacterioplankton in the Caribbean Sea, time-series measurements of chlorophyll a concentration, bacterial abundance, and thymidine incorporation rate were performed at 6 stations near Barbados. In addition, a series of incubation experiments was carried out with seawater samples collected from various depths and stations to determine bacterial growth rates and removal rates by bacterivory. Vertically integrated phytoplankton and bacterioplankton biomasses averaged 1290 and $1200 \mathrm{mg} \mathrm{C} \mathrm{m}^{-2}$, respectively, and heterotrophic bacterial production was $106 \mathrm{mg} \mathrm{C} \mathrm{m}^{-2}$, with in situ bacterial growth of $0.1 \mathrm{~d}^{-1}$. Approximately halfway through the sampling period, surface salinity dropped by as much as 4 following the arrival of water from the Amazon River. No subsequent change, however, was noted in chlorophyll $a$ concentration, bacterial abundance, or bacterial production. Averaged bacterial growth and bacterivory determined from bottle incubation experiments were 0.6 and $0.5 \mathrm{~d}^{-1}$, respectively, suggesting that predation was a major sink of daily bacterial biomass production. Both regression analysis of bacterial biomass and production and measurements of growth and bacterivory from incubation experiments suggest that top-down processes control bacterioplankton dynamics to a greater degree than bottom-up processes.
\end{abstract}

KEY WORDS: The Caribbean Sea $\cdot$ Bacterial growth $\cdot$ Bacterivory $\cdot$ Amazon River discharge Resale or republication not permitted without written consent of the publisher

\section{INTRODUCTION}

Bacterioplankton is one of the key constituents of planktonic food webs. It frequently comprises a significant fraction of planktonic biomass in oceanic waters (Ferguson \& Rublee 1976, Cho \& Azam 1988, Fuhrman et al. 1989) and bacterial metabolism may exceed that of phytoplankton in oligotrophic environments (del Giorgio et al. 1997). Bacteria utilize dissolved organic carbon, incorporate it into particulate biomass, and thereby help to mediate cycling of nutrients and materials in seawater (Azam et al. 1983, Cho \& Azam 1988, Fuhrman 1992). In addition to this energetic view of bacteria in planktonic food webs, bacterial growth rep-

*E-mail: kchoi@odu.edu resents the ultimate microbial response to the ambient environmental condition (Cooper 1991). Thus, to understand the function and structure of the planktonic food web, it is necessary to quantify in situ bacterial growth and removal by bacterivory and viral lysis (Wright \& Coffin 1984, Ducklow \& Hill 1985a, Fuhrman 1999).

The majority of oceanic waters is characterized by low nutrient concentrations; thus, bacterial growth in these environments is consistently limited by substrate supply (Morita 1997). Sanders et al. (1992) proposed that planktonic biomass and production in oligotrophic waters are more likely substrate-limited, whereas predation more likely controls them in eutrophic environments. In a more complicated scenario, Ducklow (1992) proposed that substrate-limited control of oceanic bacterioplankton growth in spring shifts to 


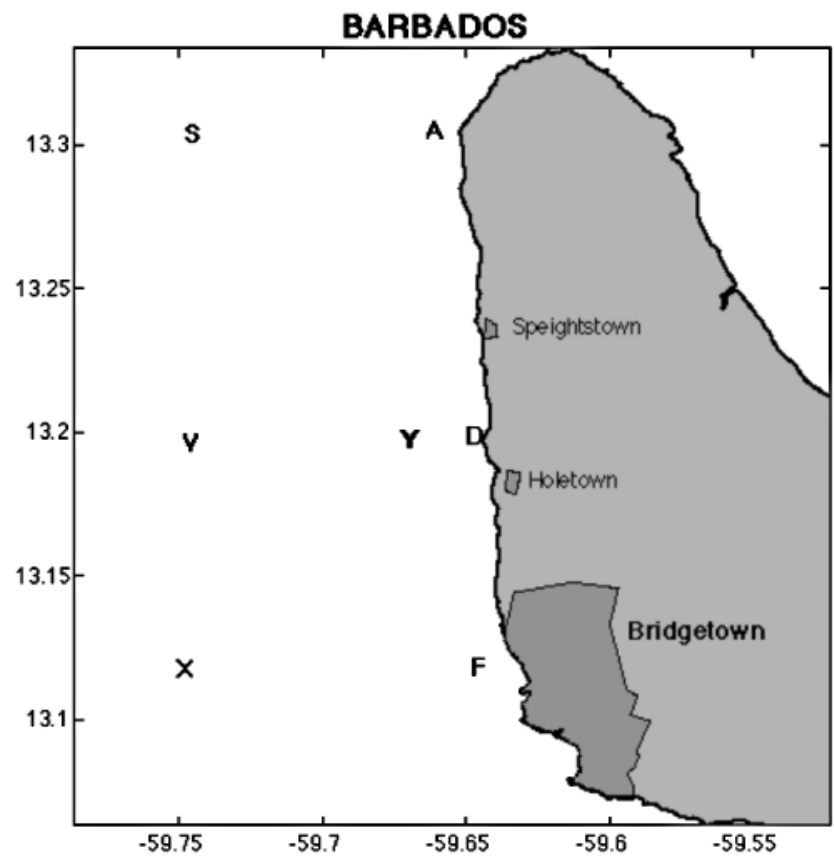

Fig. 1. Map showing sampling sites, indicated by letters, nearby and to the west of Barbados (courtesy of Peter Kelly, MSRC SUNY Stony Brook, New York, USA)

top-down control in summer. In spite of their low nutrient concentrations in the open ocean, however, high bacterial biomass and production relative to phytoplankton biomass, and bacterial growth rates comparable to those in estuarine and coastal waters have often been reported (Ducklow \& Carlson 1992 and references therein). This phenomenon of relatively high bacterial growth can be explained by the fact that nutrient limitation can be relieved in part by regeneration of nutrients through in situ grazing (Ducklow 1983, Fuhrman 1992 and references therein), although resource supply will be set by primary production. Unusually low rates of bacterivory, however, have been observed occasionally in oceanic waters (Ducklow \& Carlson 1992, Ducklow et al. 1992). Research on bacterial growth and bacterivory is less well-articulated in nutrient-limited environments as opposed to eutrophic environments (Ducklow \& Carlson 1992, Morita 1997).

The Caribbean Sea comprises a significant fraction of the western North Atlantic Ocean and generally fluctuates little in its hydrographic conditions except for periods of freshwater discharge from the Orinoco and Amazon Rivers (Muller-Karger 1988, MullerKarger et al. 1989). The freshwater input to the study area causes a steady decrease of surface salinity and increased nutrient concentration (Borstad 1982a,b). In addition, the freshwater discharge causes oscillatory variations of phytoplankton biomass, with about a 4 mo periodicity driven by the blooming and waning of
Trichodesmium sp., a nitrogen-fixing cyanobacterium found at the base of the euphotic zone off Barbados (Steven \& Glombitza 1972, Muller-Karger et al. 1989). On a shorter temporal scale, the biomass of heterotrophic bacterioplankton and protists varies severalfold over a diel cycle in the Caribbean Sea, driven by bacterial utilization of organic materials released by phytoplankton (Burney et al. 1982).

Although these earlier studies provide a general picture of phytoplankton and bacterial populations in the Caribbean Sea, quantitative information concerning microbial growth rates, especially of heterotrophic bacteria, and their controlling factors, is scarce. In this study, we expand upon earlier works and focus on a series of stations in the vicinity of Barbados. We present short-term (approximately $1 \mathrm{mo}$ ) temporal and spatial variations of chlorophyll a ( $\mathrm{chl} a)$, bacterial abundance, and bacterial production, together with concomitant measurements of bacterial growth and bacterivory.

\section{MATERIALS AND METHODS}

Study site and water collection. Six stations (Stns A, D, F, S, V, and X) were occupied from April 30 through May 25, 1997, to the west of Barbados in the Caribbean Sea (Fig. 1; for details on Stn Y, refer to 'Bacterial growth and bacterivory from bulk incubation' section). Seawater samples for chl $a$, bacterial biomass, and bacterial production were collected every 3 or $4 \mathrm{~d}$ during the study period. Samples were collected using $121 \mathrm{Go}-$ Flo bottles during CTD casts through the upper 100 to $120 \mathrm{~m}$ at Stns A, D, and F or upper $160 \mathrm{~m}$ at Stns S, V, and $\mathrm{X}$. Six to 9 water samples were obtained along a depth profile at each station and at each sampling time. Seawater samples were collected from Stns A, D, and F (defined hereafter as nearshore stations) during the day and from Stns S, V, and X (defined as offshore stations) at night. Upon recovery, seawater was transferred to opaque 11 Nalgene bottles via non-toxic Teflon tubing. All incubation bottles and tubing had been rinsed with $5 \% \mathrm{HCl}$, then Milli-Q water, and finally with seawater.

Measurements of plankton biomass and production. To quantify chl a concentration, $150 \mathrm{ml}$ of seawater was filtered onto $25 \mathrm{~mm} \mathrm{GF/F} \mathrm{filters,} \mathrm{then} \mathrm{measured} \mathrm{fluoro-}$ metrically following an acetone extraction method corrected for the presence of pheophytins (Parsons et al. 1992).

For bacterial enumeration, $10 \mathrm{ml}$ seawater samples were fixed with $1 \%$ (final concentration) formaldehyde and stored at $4{ }^{\circ} \mathrm{C}$. Bacterial counts were made following a standard 4'6'-diamidino-2-phenylindole (DAPI) staining technique (Porter \& Feig 1980). The samples were filtered onto $0.2 \mu \mathrm{m}$ black Poretic filters, stained with $1 \mathrm{\mu g}^{-1}$ DAPI (final concentration), and mounted 
onto glass slides using Cargille type F immersion oil. Slides were prepared within a few days of sampling and stored at $-20^{\circ} \mathrm{C}$ on board ship and at $-85^{\circ} \mathrm{C}$ in the laboratory until examination. Bacteria were enumerated by examining 20 fields at $1250 \times$ magnification using epifluorescence microscopy. An Olympus BX50 microscope was used with a mercury lamp, BP 330-385 excitation filter and BA 420 barrier filter.

Bacterial production was measured by the incorporation of [methyl- $\left.{ }^{3} \mathrm{H}\right]$ thymidine $(\mathrm{TdR}$, specific activity $80.3 \mathrm{Ci} \mathrm{mmol}^{-1}$, Amersham Inc.) into bacterial macromolecules. Seawater samples of 20 to $40 \mathrm{ml}$ were transferred to glass vials or $50 \mathrm{ml}$ plastic tubes and amended with $10 \mathrm{nM}$ (final concentration) of ${ }^{3} \mathrm{H}$-thymidine. Samples were incubated in containers filled with seawater collected from the corresponding depths, in reduced light for water samples from depths $<60 \mathrm{~m}$, and in the dark for water samples collected below $60 \mathrm{~m}$. Formaldehyde-killed control samples were used to determine abiotic and other effects. Incubation of samples was terminated by adding formaldehyde (final concentration, $1 \%$ ). Samples were kept at $4^{\circ} \mathrm{C}$ until they were filtered onto $0.2 \mu \mathrm{m}$ cellulose-nitrate membrane filters. The filters were washed 3 times with $5 \%$ ice-cold trichloroacetic acid (TCA), and 3 times with $80 \%$ ice-cold ethanol. The filters were dissolved in $1 \mathrm{ml}$ of ethyl acetate, scintillation cocktail (Fisher Scientific Inc.) was added, and radioactivity was counted with a LS 5000 TD scintillation counter (Beckman Inc.).

Bacterial growth and bacterivory from bulk incubation. For bacterial growth experiments, seawater samples were collected using 121 Go-Flo bottles at various times from several depths at Stns A, S, and Y (Table 1, Fig. 1). Freshly collected seawater was transferred to a 201 carboy or 21 polycarbonate bottles via Teflon tubing. All incubation bottles and tubing were previously rinsed with $\mathrm{HCl}(5 \%)$, copious Milli-Q water, and finally seawater. Particle-free seawater $(0.2 \mu \mathrm{m}$ filtrate) was obtained using sequential filtering through 3 and $0.2 \mu \mathrm{m}$ Gelman Versapor filters and the first 21 of filtrate was discarded. One part of whole water (undiluted) was diluted with 4 parts of particle-free seawater to make 21 water samples. Diluted and whole water samples collected from $40 \mathrm{~m}$ depth were incubated in reduced light in a deck incubator overflowing with ambient surface seawater $\left(\mathrm{ca} 30^{\circ} \mathrm{C}\right)$. The water samples collected from 100 and $160 \mathrm{~m}$ were incubated in the dark at 2 to $3^{\circ} \mathrm{C}$ elevated temperatures relative to in situ temperatures (ca $27^{\circ} \mathrm{C}$ for $100 \mathrm{~m}$ samples and ca $22^{\circ} \mathrm{C}$ for the samples from $160 \mathrm{~m}$ ). Subsamples were withdrawn over a period of up to $56 \mathrm{~h}$ to determine bacterial counts.

On one occasion, bacterial cell volumes were measured using samples taken for bacterial counts in a growth-rate experiment. These samples were collected on May 12 at Stn Y from depths of 40, 100, and $160 \mathrm{~m}$.
Table 1. Summary of water sampling and treatments for bacterial growth experiments

\begin{tabular}{|c|c|c|c|c|c|}
\hline Date & Stn & $\begin{array}{l}\text { Depth } \\
\text { (m) }\end{array}$ & $\begin{array}{c}\% \text { inoculum } \\
\text { diluted with } \\
\text { particle-free } \\
\text { water }\end{array}$ & $\begin{array}{c}\text { Incu- } \\
\text { bation } \\
\text { temp. } \\
\left({ }^{\circ} \mathrm{C}\right)\end{array}$ & $\begin{array}{c}\text { Incu- } \\
\text { bation } \\
\text { duration } \\
\text { (h) }\end{array}$ \\
\hline $\begin{array}{l}\text { May } 4 \\
\text { May } 4\end{array}$ & $\begin{array}{l}\mathrm{Y} \\
\mathrm{Y}\end{array}$ & $\begin{array}{l}40 \\
40\end{array}$ & $\begin{array}{r}0 \\
80\end{array}$ & $\begin{array}{l}29.5 \\
29.5\end{array}$ & $\begin{array}{l}48 \\
48\end{array}$ \\
\hline $\begin{array}{l}\text { May } 12 \\
\text { May } 12\end{array}$ & $\begin{array}{l}\mathrm{A} \\
\mathrm{A}\end{array}$ & $\begin{array}{l}40 \\
40\end{array}$ & $\begin{array}{r}0 \\
80\end{array}$ & $\begin{array}{l}29.8 \\
29.8\end{array}$ & $\begin{array}{l}49 \\
49\end{array}$ \\
\hline $\begin{array}{l}\text { May } 12 \\
\text { May } 12\end{array}$ & $\begin{array}{l}\mathrm{Y} \\
\mathrm{Y}\end{array}$ & $\begin{array}{r}40 \\
40 \\
100 \\
100 \\
160 \\
160\end{array}$ & $\begin{array}{r}0 \\
80 \\
0 \\
80 \\
0 \\
80\end{array}$ & $\begin{array}{l}30.0 \\
30.0 \\
26.5 \\
26.5 \\
22.0 \\
22.0\end{array}$ & $\begin{array}{l}56 \\
56 \\
56 \\
56 \\
56 \\
56\end{array}$ \\
\hline $\begin{array}{l}\text { May } 13 \\
\text { May } 13\end{array}$ & $\begin{array}{l}\mathrm{S} \\
\mathrm{S}\end{array}$ & $\begin{array}{l}40 \\
40\end{array}$ & $\begin{array}{r}0 \\
80\end{array}$ & $\begin{array}{l}29.3 \\
29.3\end{array}$ & $\begin{array}{l}56 \\
56\end{array}$ \\
\hline $\begin{array}{ll}\text { May } 19 \\
\text { May } 19\end{array}$ & $\begin{array}{l}\mathrm{Y} \\
\mathrm{Y}\end{array}$ & $\begin{array}{l}40 \\
40\end{array}$ & $\begin{array}{r}0 \\
80\end{array}$ & $\begin{array}{l}30.5 \\
30.5\end{array}$ & $\begin{array}{l}56 \\
56\end{array}$ \\
\hline
\end{tabular}

Cell volumes were determined at the beginning $(0 \mathrm{~h})$ and at the end ( $56 \mathrm{~h}$ ) of the incubation. Bacteria were stained with acridine orange (AO), and photographed at $1000 \times$ magnification using print film (Kodak 400 ASA). The prints were examined under a stereo microscope and approximately 150 bacterial cells were sized; only the bright inner edge was measured. The final magnification was about $10000 \times$. Bacterial size was calibrated using various sizes of fluorescently labeled beads (Molecular Probes, Inc.).

Bacterial growth rates and removal rates by grazing were calculated based on the equations of Landry \& Hassett (1982), as modified by Ducklow \& Hill (1985a):

$$
\begin{gathered}
R_{\mathrm{n}}=\mu-g \\
R_{\mathrm{d}}=\mu-X g
\end{gathered}
$$

where $R_{\mathrm{n}}$ and $R_{\mathrm{d}}$ represent net bacterial growth rate within whole and diluted water, respectively, $\mu$ is gross growth rate, $g$ is grazing rate, and $X$ is the dilution factor, 0.2 here, since the whole water was diluted 5 -fold with particle-free water. $R_{\mathrm{n}}$ and $R_{\mathrm{d}}$ were obtained from the slopes of time versus natural-log-transformed bacterial abundance (Ducklow \& Hill 1985a). Since $R_{\mathrm{n}}, R_{\mathrm{d}}$ and $X$ were known, the values of $\mu$ and $g$ could be calculated. Bacterial growth rates and removal rates were also calculated using biovolume (abundance $\times$ mean cell volume) data (Ducklow et al. 1992).

\section{RESULTS}

\section{Hydrographic conditions}

Mean water temperature at the surface was about $28^{\circ} \mathrm{C}$, changed little (generally $<2^{\circ} \mathrm{C}$ ) down to $80 \mathrm{~m}$ 

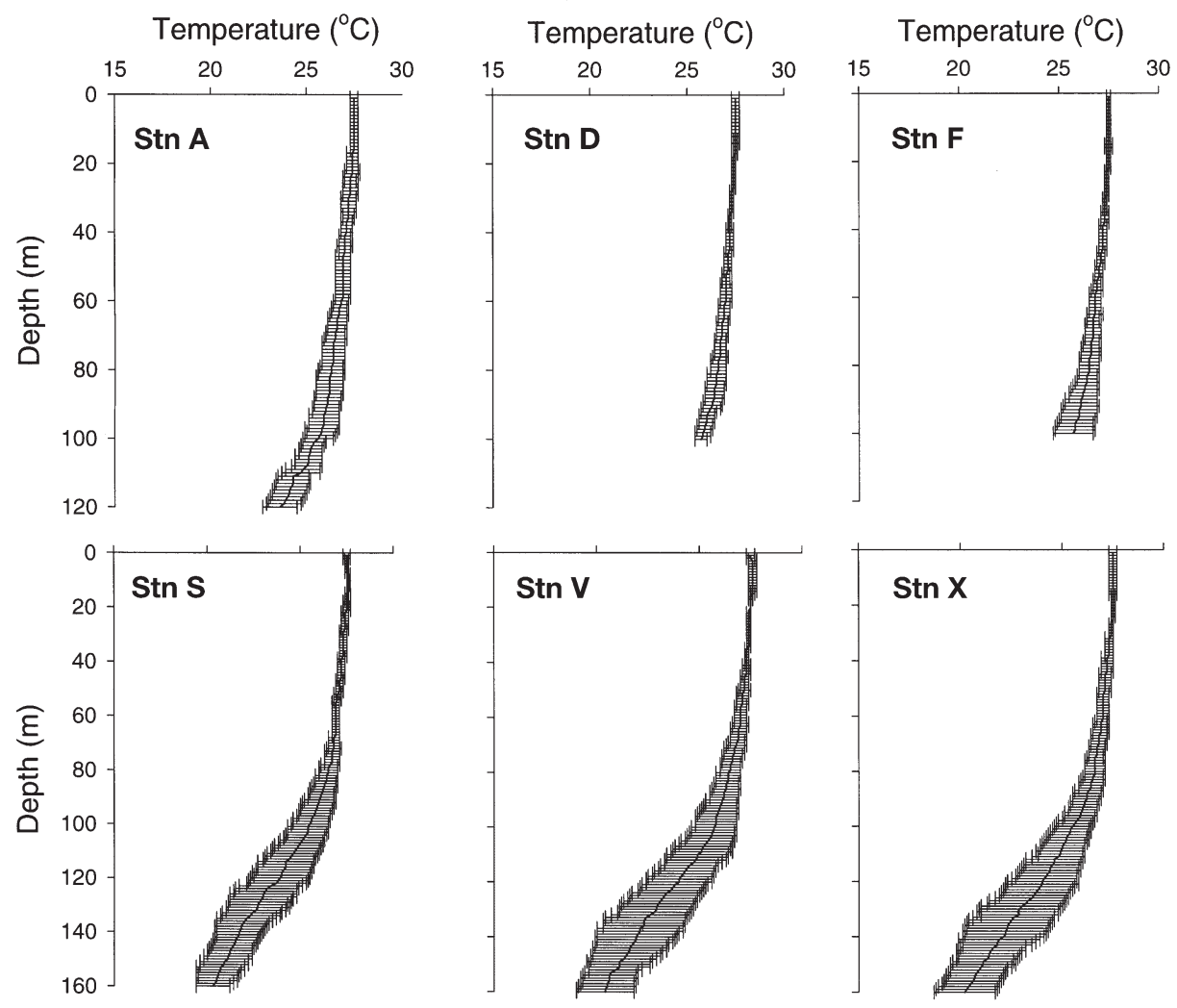

Fig. 2. Vertical profile of temperature at each station. A total of 8 casts for temperature were made at each station during the study period. Horizontal bars represent 1 standard deviation (courtesy of Peter Kelly, MSRC SUNY Stony Brook, New York, USA)
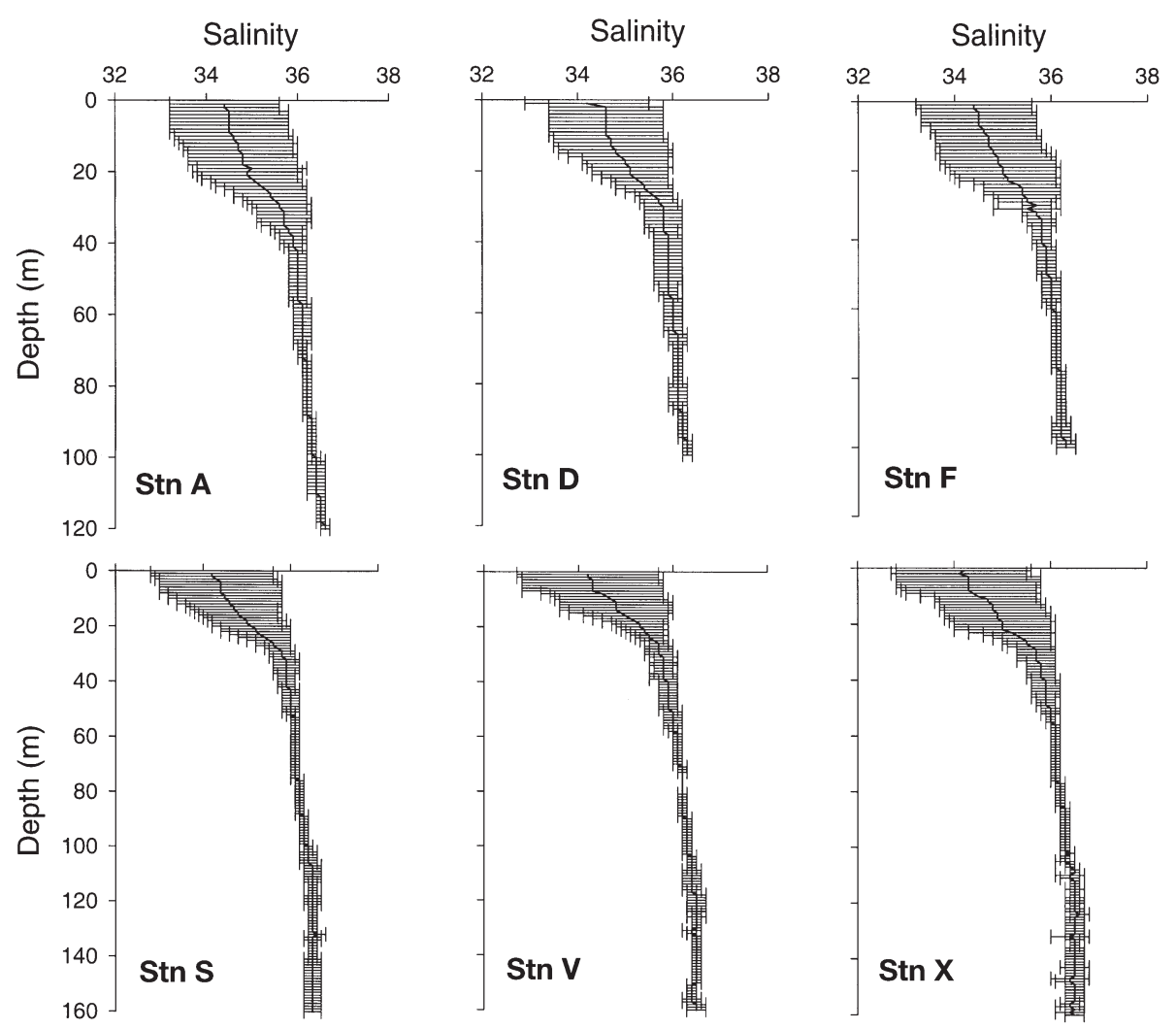

Fig. 3. Vertical profile of salinity at each station. A total of 8 casts for salinity were made at each station during the study period. Horizontal bars represent 1 standard deviation (courtesy of Peter Kelly, MSRC SUNY Stony Brook, New York, USA) 
depth, and then rapidly decreased to $20^{\circ} \mathrm{C}$ at $160 \mathrm{~m}$ depth (Fig. 2). Interstation variation of water temperature was minimal (Fig. 2). Water temperature exhibited little temporal variation in the upper $80 \mathrm{~m}$ depth, whereas temporal variation below $80 \mathrm{~m}$ ranged nearly $5^{\circ} \mathrm{C}$ during the study period (Fig. 2).

Salinities were typical of the open ocean (ca 35) and increased slightly with depth down to $40 \mathrm{~m}$, then were almost constant with depth (Fig. 3). Almost no inter-station variation in salinity was detected. Salinity displayed substantial temporal variation $(\sim 3)$ in the upper $40 \mathrm{~m}$ of the water column. This variation was caused by the introduction to the area, beginning around May 15, of relatively low salinity water from the Amazon River, indicated by a ${ }^{228} \mathrm{Ra} /{ }^{226} \mathrm{Ra}$ ratio of approximately 1, characteristic of the Amazon River mixing zone (Kelly et al. 2000).

\section{Spatial variation of biomass, production, and growth}

Average chl a concentrations were $<0.4 \mathrm{mg} \mathrm{m}^{-3}$ at all stations during the period of the study. Chl a concentrations showed subsurface maxima and those maxima were relatively shallower, between 40 and $60 \mathrm{~m}$, at 2 nearshore stations (Stns A and D) than at offshore stations (Fig. 4).

Mean bacterial abundance was greatest at the surface $\left(0.7 \times 10^{9}\right.$ cells $\left.\mathrm{l}^{-1}\right)$ and decreased to minimum values $\left(0.2 \times 10^{9}\right.$ cells $\left.\mathrm{l}^{-1}\right)$ at $160 \mathrm{~m}$ depth (Fig. 5). Depth-integrated bacterial $\mathrm{C}$ biomass was equivalent to about 73 to $111 \%$ of phytoplankton POC (Table 2). Neither depth-integrated phytoplankton biomass nor bacterioplankton biomass exhibited significant inter-station differences (Table 2). The ratio of bacterioplankton to phytoplankton biomass, however, was significantly higher at Stn $\mathrm{X}$ than at Stns A and D.

Thymidine incorporation rate either decreased slightly with depth (Stn A) or showed no discernable change with
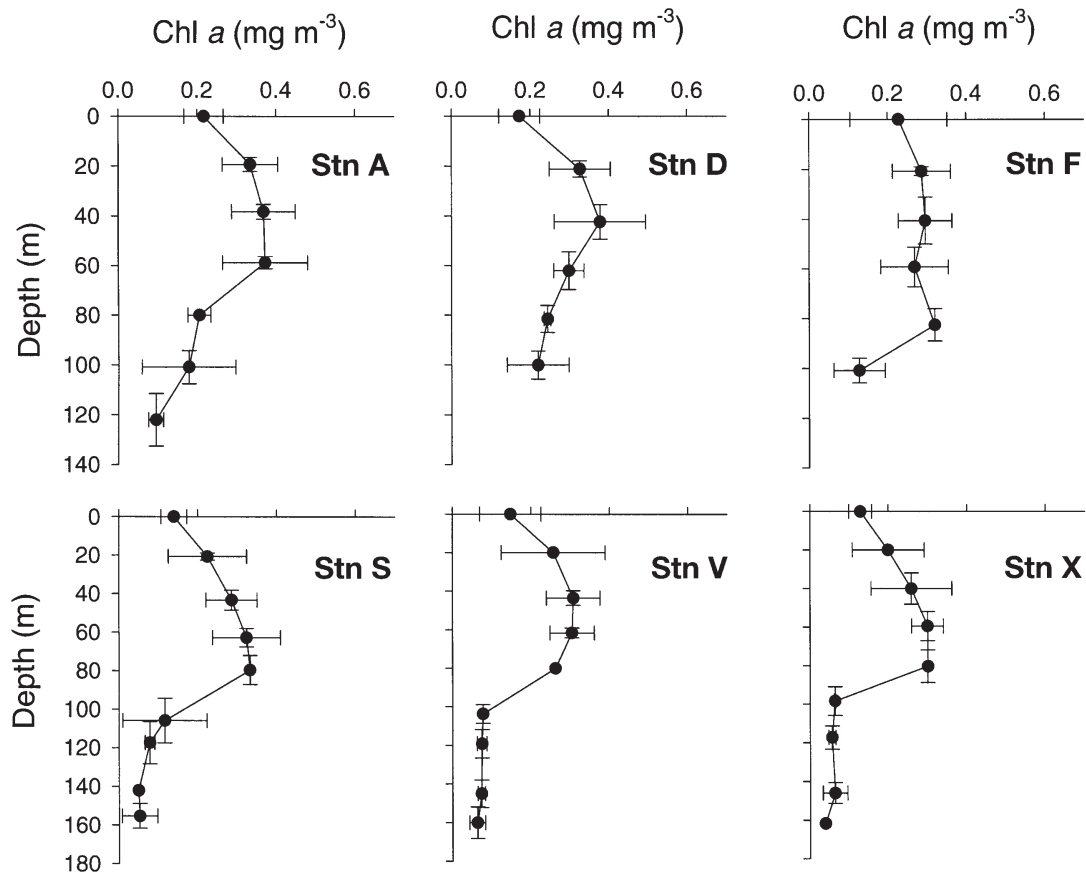

Fig. 4. Vertical profile of chlorophyll a concentration at each station. A total of 5 casts for chlorophyll were made at each station during the study period. Vertical and horizontal bars represent 1 standard deviation
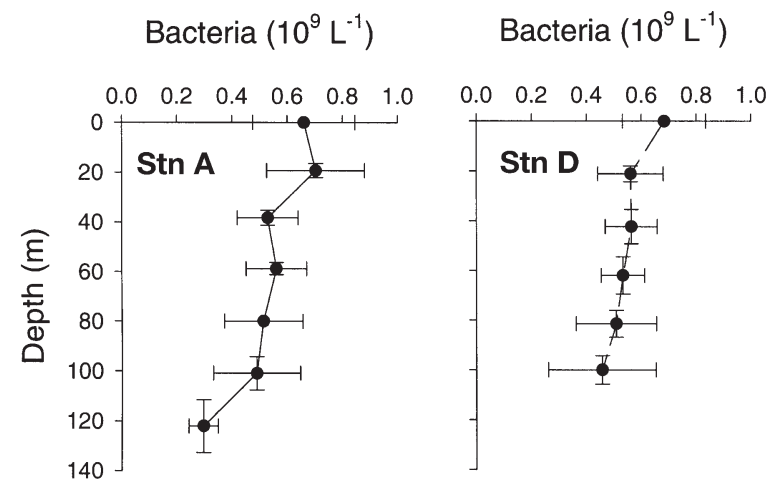

Bacteria $\left(10^{9} \mathrm{~L}^{-1}\right)$
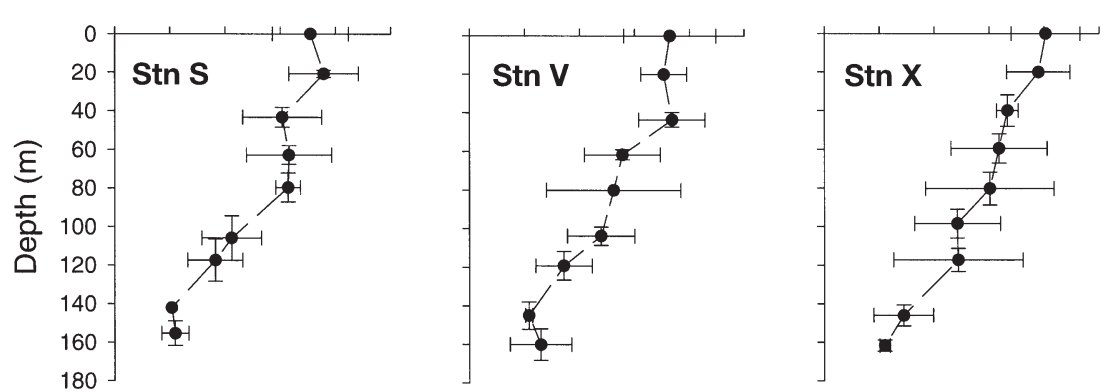

Fig. 5. Vertical profile of bacterial abundance at each station. A total of 8 casts for bacterial abundance were made at each station during the study period. Vertical and horizontal bars represent 1 standard deviation 
Table 2. Comparison among stations of vertically integrated, average values (standard deviation) in the euphotic zone. (The actual euphotic depth was between 110 and $120 \mathrm{~m}$. However, no biological measurements were performed below $100 \mathrm{~m}$ at nearshore stations. To facilitate comparisons between nearshore and offshore stations, measures shown here represent values integrated

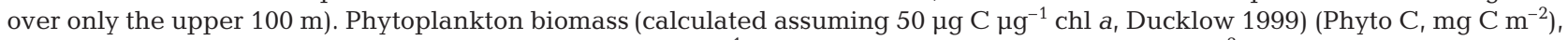
bacterioplankton biomass (computed assuming $20 \mathrm{fg} \mathrm{C} \mathrm{cell}^{-1}$, Lee \& Fuhrman 1987) (Bac C, mg C m ${ }^{-2}$ ), ratio of bacterial biomass to phytoplankton biomass (Bac C/Phyto C), bacterial production (calculated from thymidine incorporation rate assuming $1.6 \times$ $10^{18}$ cells mol ${ }^{-1}$, Ducklow 1999) (Bac P, $\mathrm{mg} \mathrm{C} \mathrm{m}^{-2} \mathrm{~d}^{-1}$ ), and bacterial growth (Bac $\mathrm{G}_{1} \mathrm{~d}^{-1}$ ). Superscripted letters represent results of Tukey's HSD test; values with the same letter are not significantly different at a family error rate of 0.05

\begin{tabular}{|c|c|c|c|c|c|c|c|}
\hline \multirow{2}{*}{ Parameter } & \multicolumn{6}{|c|}{ Stn } & \multirow{2}{*}{ Grand mean } \\
\hline & A & $\mathrm{D}$ & $\mathrm{F}$ & $\mathrm{S}$ & $\mathrm{V}$ & $\mathrm{X}$ & \\
\hline Phyto C & $\begin{array}{l}1523^{\mathrm{a}} \\
(191)\end{array}$ & $\begin{array}{l}1411^{\mathrm{a}} \\
(291)\end{array}$ & $\begin{array}{l}1192^{\mathrm{a}} \\
(162)\end{array}$ & $\begin{array}{l}1250^{\mathrm{a}} \\
(209)\end{array}$ & $\begin{array}{l}1264^{\mathrm{a}} \\
(206)\end{array}$ & $\begin{array}{l}1112^{\mathrm{a}} \\
(205)\end{array}$ & $\begin{array}{l}1291 \\
(238)\end{array}$ \\
\hline Bac C & $\begin{array}{l}1138^{a} \\
(211)\end{array}$ & $\begin{array}{l}1047^{a} \\
(210)\end{array}$ & $\begin{array}{l}1142^{\mathrm{a}} \\
(204)\end{array}$ & $\begin{array}{l}1270^{\mathrm{a}} \\
(217)\end{array}$ & $\begin{array}{l}1265^{a} \\
(112)\end{array}$ & $\begin{array}{l}1331^{a} \\
(188)\end{array}$ & $\begin{array}{l}1199 \\
(208)\end{array}$ \\
\hline Bac C/Phyto C & $\begin{array}{c}0.73^{\mathrm{a}} \\
(0.15)\end{array}$ & $\begin{array}{c}0.76^{\mathrm{a}} \\
(0.07)\end{array}$ & $\begin{array}{l}0.92^{\mathrm{ab}} \\
(0.06)\end{array}$ & $\begin{array}{l}1.02^{\mathrm{ab}} \\
(0.30)\end{array}$ & $\begin{array}{l}0.98^{\mathrm{ab}} \\
(0.18)\end{array}$ & $\begin{array}{l}1.11^{b} \\
(0.09)\end{array}$ & $\begin{array}{c}0.93 \\
(0.21)\end{array}$ \\
\hline Bac $\mathrm{P}$ & $\begin{array}{l}20^{\mathrm{a}} \\
(3)\end{array}$ & $\begin{array}{l}50^{\mathrm{ab}} \\
(59)\end{array}$ & $\begin{array}{l}67^{\mathrm{bc}} \\
(21)\end{array}$ & $\begin{array}{l}139^{c} \\
(68)\end{array}$ & $\begin{array}{l}148^{\mathrm{c}} \\
(67)\end{array}$ & $\begin{array}{l}147^{\mathrm{c}} \\
(52)\end{array}$ & $\begin{array}{l}101 \\
(67)\end{array}$ \\
\hline Bac G & $\begin{array}{c}0.02^{\mathrm{a}} \\
(0.00)\end{array}$ & $\begin{array}{l}0.06^{\mathrm{ab}} \\
(0.08)\end{array}$ & $\begin{array}{l}0.07^{b c} \\
(0.03)\end{array}$ & $\begin{array}{c}0.11^{\mathrm{c}} \\
(0.06)\end{array}$ & $\begin{array}{c}0.12^{\mathrm{c}} \\
(0.05)\end{array}$ & $\begin{array}{c}0.11^{\mathrm{c}} \\
(0.04)\end{array}$ & $\begin{array}{c}0.08 \\
(0.05)\end{array}$ \\
\hline
\end{tabular}

depth (Fig. 6). Average thymidine incorporation rates were 0.1 to $1.5 \mathrm{pmol}^{-1} \mathrm{~h}^{-1}$ at nearshore stations and 1.2 to $2.4 \mathrm{pmol}^{-1} \mathrm{~h}^{-1}$ at offshore stations. Both bacterial pro- duction (estimated from thymidine incorporation rate) and growth rates (computed from bacterial production divided by bacterial biomass) were significantly greater at offshore stations than at nearshore stations A and D (Table 2).
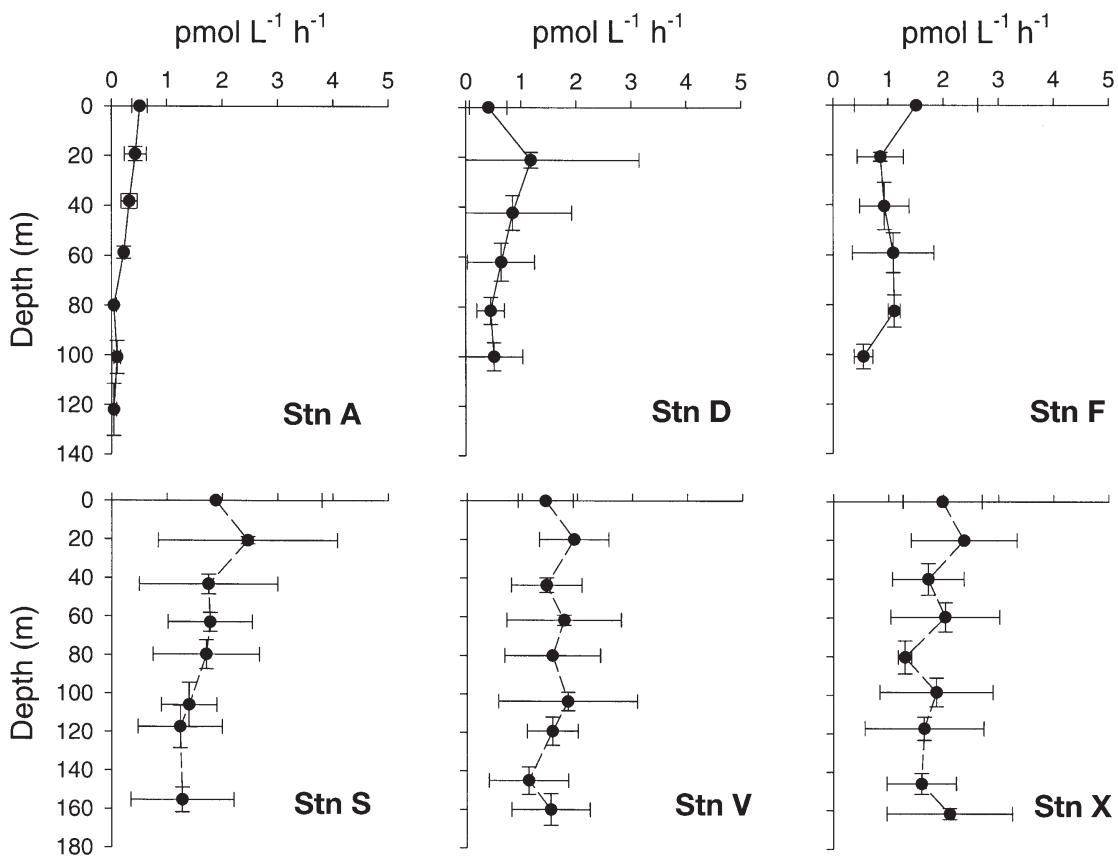

Fig. 6. Vertical profile of [methyl- $\left.{ }^{3} \mathrm{H}\right]$ thymidine incorporation rate at each station. A total of 5 casts at nearshore stations and 8 casts at offshore stations were made during the study period. Vertical and horizontal bars represent 1 standard deviation

\section{Temporal variation of biomass, production, and growth}

There were temporal variations in plankton biomass, production, and growth rates at all stations (Fig. 7). Phytoplankton biomass and bacterioplankton biomass varied as much as 2-fold, exhibited tight or slightly delayed couplings (Fig. 7), and yielded a positive linear regression when the latter was regressed on the former $\left(\mathrm{r}^{2}=0.13\right.$, regression slope $=0.41, \mathrm{p}<0.05$, $\mathrm{n}=26$ ). Bacterial production was coupled to phytoplankton biomass with a greater time lag, yielding a negative regression of production on biomass $\left(\mathrm{r}^{2}=0.31\right.$, regression slope $=-0.56, \mathrm{p}<0.01, \mathrm{n}=28)$. Bacterial growth tracked the pattern of bacterial production more so than that of bacterial biomass. 
Fig. 7. Temporal variation of phytoplankton biomass (Phyto C), bacterioplankton biomass (Bac C), and bacterioplankton production (Bac P), expressed as values integrated through the euphotic zone. Note that the scale of bacterial production stations at Stn A has a lesser range than at other
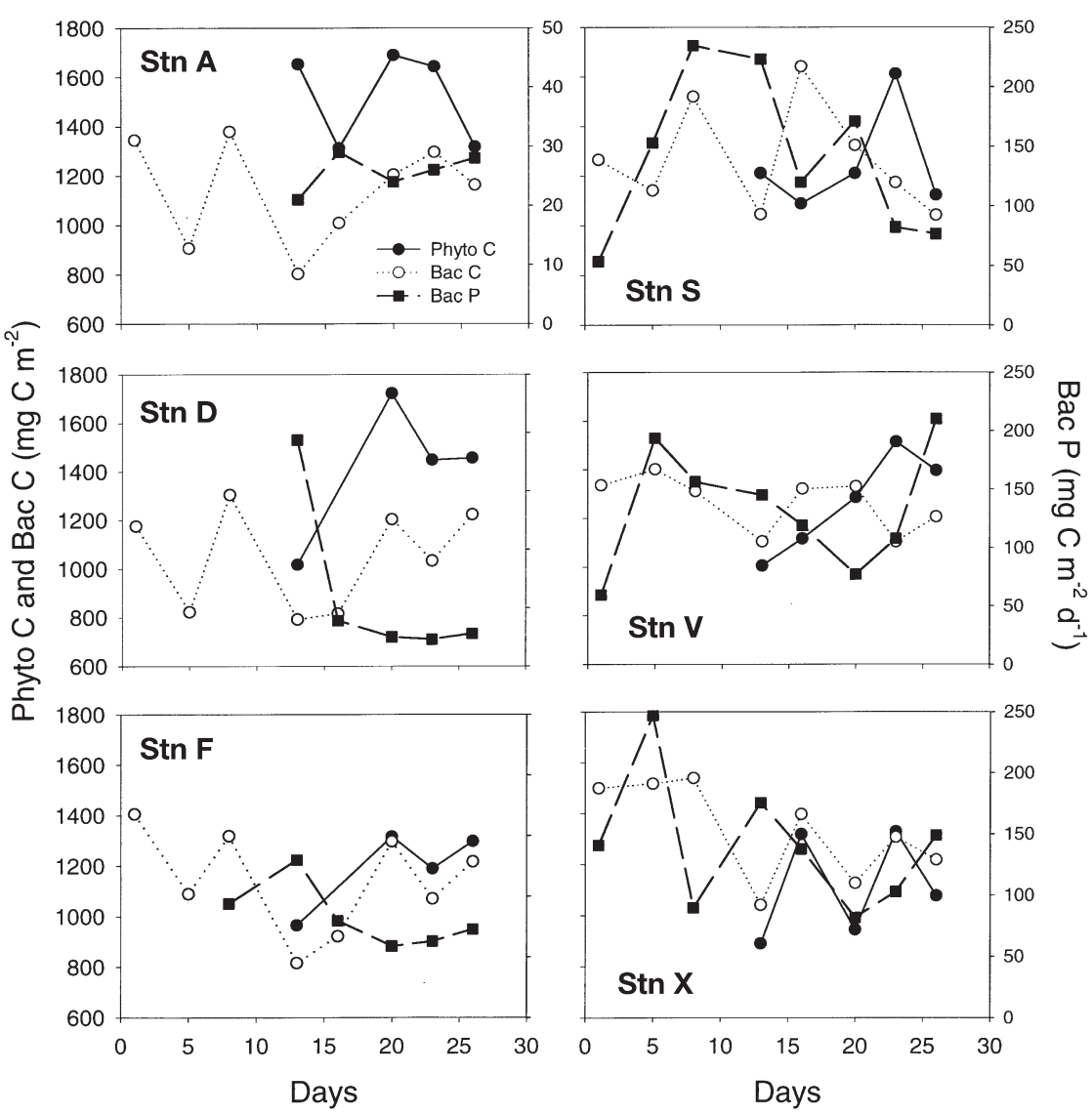

The effect of the Amazon River plume on planktonic biomass and production

To assess the effect of the Amazon River plume on the biomass of phyto- and bacterioplankton as well as on bacterial production, the relationship of chl $a$, bacterial abundance, and bacterial production to salinity was examined. Surface salinity dropped from 36 to 32 after the lower salinity water arrived. However, there was no subsequent increase or decrease in chl a concentration, bacterial abundance, or bacterial production following the introduction of low salinity water through the upper $40 \mathrm{~m}$ surface layer (Fig. 8).

\section{Bacterial growth and bacterivory in incubation experiments}

Based on cell abundance, bacteria grew at rates of 0.38 to $0.85 \mathrm{~d}^{-1}$ with generation times of 28 to $63 \mathrm{~h}$. Bac-

Fig. 8. Effect of the Amazon River plume on chl a concentration, bacterial abundance, and bacterial production (TdR) in the upper $40 \mathrm{~m}$ of the study area. Before: before arrival of the saline water, After: after arrival of less saline water
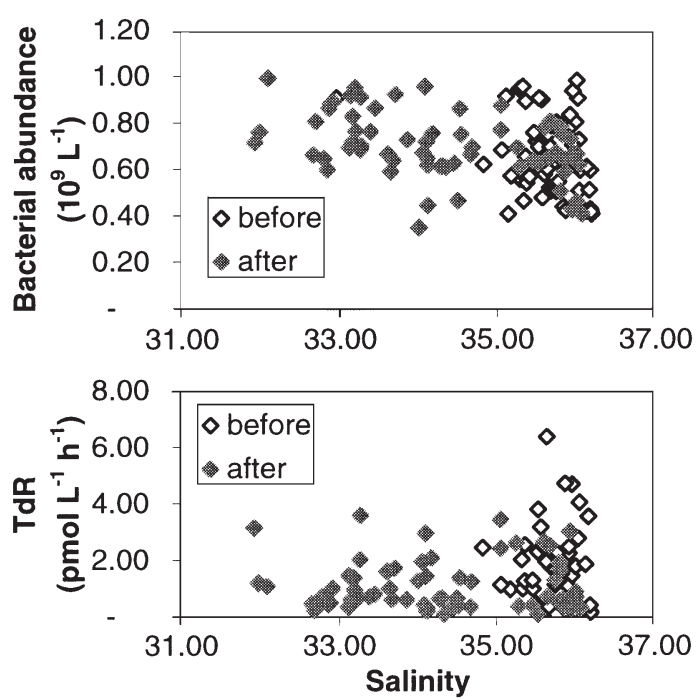

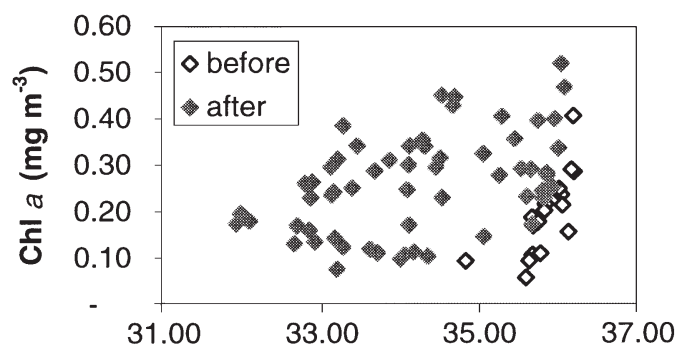


Table 3. Bacterial growth $(\mu)$ and removal rates $(g)$ estimated by the dilution approach. Cell: rates based on bacterial abundance; Biovolume: based on bacterial biovolume

\begin{tabular}{|c|c|c|c|c|c|c|c|}
\hline \multirow[t]{2}{*}{ Date } & \multirow[t]{2}{*}{ Stn } & \multirow[t]{2}{*}{ Depth $(\mathrm{m})$} & & \multicolumn{2}{|c|}{$\mu$} & \multicolumn{2}{|c|}{$g$} \\
\hline & & & & $\left(\mathrm{h}^{-1}\right)$ & $\left(d^{-1}\right)$ & $\left(h^{-1}\right)$ & $\left(d^{-1}\right)$ \\
\hline May 4 & $\mathrm{Y}$ & 40 & Cell & 0.016 & 0.38 & 0.010 & 0.23 \\
\hline \multirow[t]{4}{*}{ May 12} & $\mathrm{~A}$ & 40 & Cell & 0.028 & 0.66 & 0.025 & 0.61 \\
\hline & $\mathrm{Y}$ & 40 & $\begin{array}{l}\text { Cell } \\
\text { Biovolume }\end{array}$ & $\begin{array}{l}0.020 \\
0.013\end{array}$ & $\begin{array}{l}0.47 \\
0.32\end{array}$ & $\begin{array}{l}0.038 \\
0.013\end{array}$ & $\begin{array}{l}0.92^{\mathrm{b}} \\
0.27\end{array}$ \\
\hline & $\mathrm{Y}$ & 100 & $\begin{array}{l}\text { Cell } \\
\text { Biovolume }\end{array}$ & $\begin{array}{l}0.035 \\
0.051\end{array}$ & $\begin{array}{l}0.85 \\
1.21\end{array}$ & $\begin{array}{l}0.032 \\
0.052\end{array}$ & $\begin{array}{l}0.77 \\
1.26\end{array}$ \\
\hline & $\mathrm{Y}$ & 160 & $\begin{array}{l}\text { Cell } \\
\text { Biovolume }\end{array}$ & $\begin{array}{l}0.022 \\
0.061\end{array}$ & $\begin{array}{l}0.52 \\
1.46\end{array}$ & $\begin{array}{l}0.013 \\
0.029\end{array}$ & $\begin{array}{l}0.31 \\
0.69\end{array}$ \\
\hline May 13 & $\mathrm{~S}$ & 40 & Cell & 0.026 & 0.63 & 0.021 & 0.49 \\
\hline May $19^{a}$ & $\mathrm{Y}$ & 40 & $\begin{array}{l}\text { Cell } \\
\text { Mean }^{b}\end{array}$ & 0.007 & $\begin{array}{l}0.16 \\
0.61\end{array}$ & -0.001 & $\begin{array}{r}-0.02 \\
0.48\end{array}$ \\
\hline
\end{tabular}

terial growth rates calculated from biovolume data were 0.32 to $1.46 \mathrm{~d}^{-1}$, with corresponding generation times of 16 to $77 \mathrm{~h}$ (Table 3 ). In 8 out of 9 incubations, bacteria increased in abundance at a rate greater in diluted samples than in whole water samples (Fig. 9). In the incubation incorporating measurements of bac-
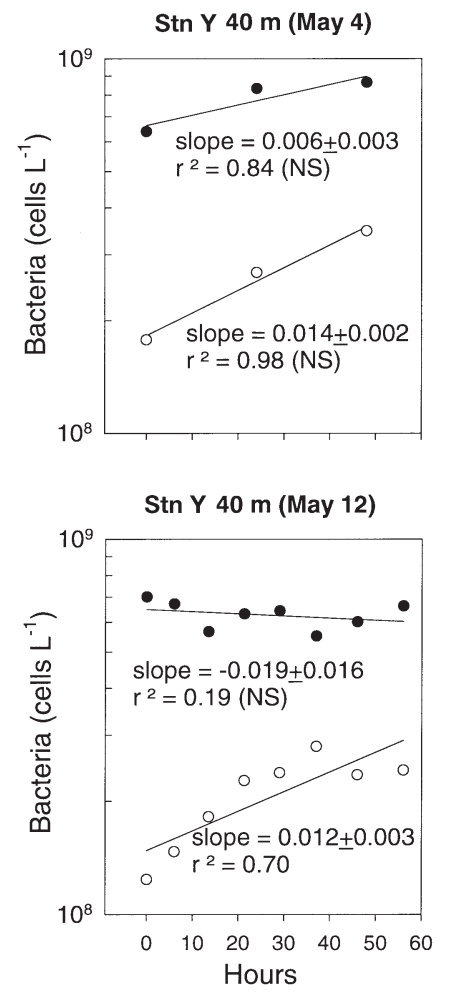
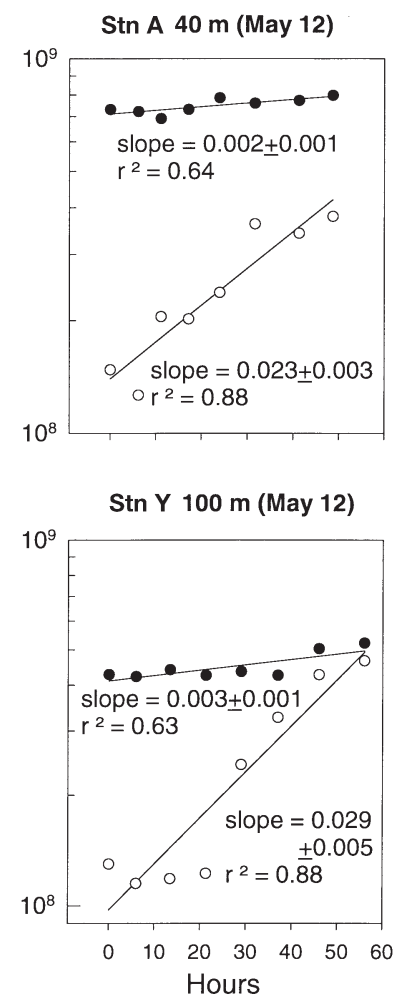

$\operatorname{Stn} Y 160 \mathrm{~m}($ May 12)
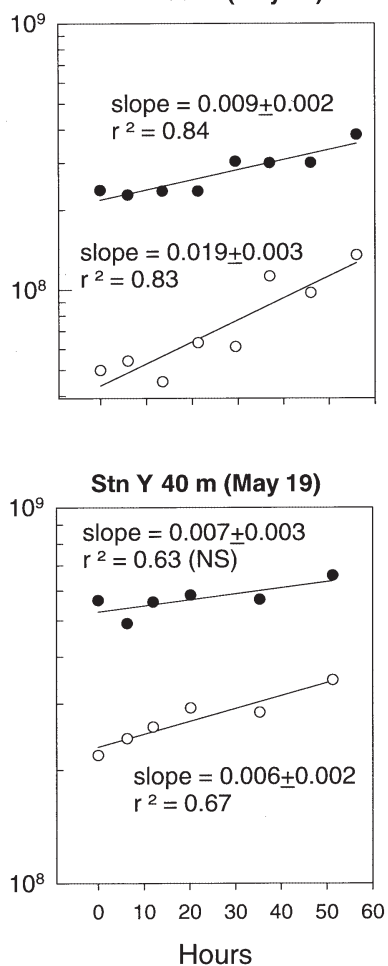

Stn S 40 m (May 13)

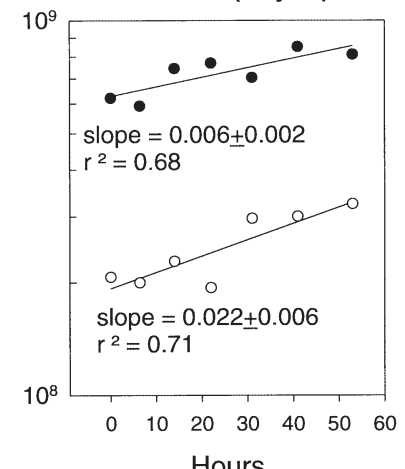

Hours

Fig. 9. Changes in bacterial abundance during incubation of seawater samples from various stations and depths. (•) Whole water samples; (O) diluted water samples. (NS: regression coefficient is not significant [ $p>0.05]$. The small number of subsamples [n = 3] from incubation of diluted water collected at $40 \mathrm{~m}$ from Stn Y on May 4 rendered the regression not significant despite the increase in cell abundance) 
terial cell volumes, significant biovolume increases occurred over time in both whole and diluted water from $160 \mathrm{~m}$ and in diluted water from $100 \mathrm{~m}$ (Fig. 10). Taken together, these results suggest that grazing by microzooplankton significantly affected bacterial abundance and, in water $100 \mathrm{~m}$ and deeper, bacterial biovolume.

The estimated rates of bacterial removal due to grazing varied across depths and sampling time and ranged from 0.23 to $0.77 \mathrm{~d}^{-1}$ (cell abundance data) and 0.27 to $1.26 \mathrm{~d}^{-1}$ (biovolume data) (Table 3). Overall, these removal rates indicate that an average of $80 \%$ of bacterial biomass produced daily could be removed by bacterivory.

\section{DISCUSSION}

Before discussion of the results, it is important first to assess the possibility that the study area's proximity to Barbados substantially affected the observations. In fact, the influence of the island on plankton biomass was indiscernible, as evidenced by similarities in chl a concentration and bacterial abundance between nearshore and offshore stations (Table 2). Furthermore, there was no evidence for any anthropogenic effect on plankton biomass, since no increased levels of chl a or bacterial abundance were detected at Stn F, near the waste-water outflow from the city of Bridgetown (Figs. 4 \& 5). Concentrations of chl $a_{1}$ on average less than $0.4 \mathrm{\mu g} \mathrm{m}^{-3}$ in the water column down to $100 \mathrm{~m}$, were quite similar to values obtained $25 \mathrm{yr}$ previously by Steven \& Glombitza (1972).

It has been of keen interest for marine microbiologists to ascertain whether bacterioplankton populations in seawater are controlled by bottom-up or topdown processes (Billen et al. 1980, Ducklow 1992, 1999, Shiah \& Ducklow 1994). Billen et al. (1980, 1990) suggested a simple approach to address the relative magnitude of bottom-up (resource supply) and topdown (e.g. predation and viral lysis) control on bacterial biomass. If bacterial biomass were limited solely by resource supply, then a strong correlation would be observed between bacterial abundance and bacterial production, assuming bacterial uptake of resource equals the rate of resource input. Following the approach of Billen et al. $(1980,1990)$, bacterioplankton biomass in this study was significantly related to bacterial production $\left(\mathrm{r}^{2}=0.10, \mathrm{p}<0.05, \mathrm{n}=40\right)$ and the regression slope was 0.32 , indicating moderate control by bottom-up processes. In contrast, bacterivory results indicate that approximately $80 \%$ of daily bacterial biomass production was removed by predation (Table 3), suggesting that top-down controls on bacterial dynamics were stronger than bottom-up processes.

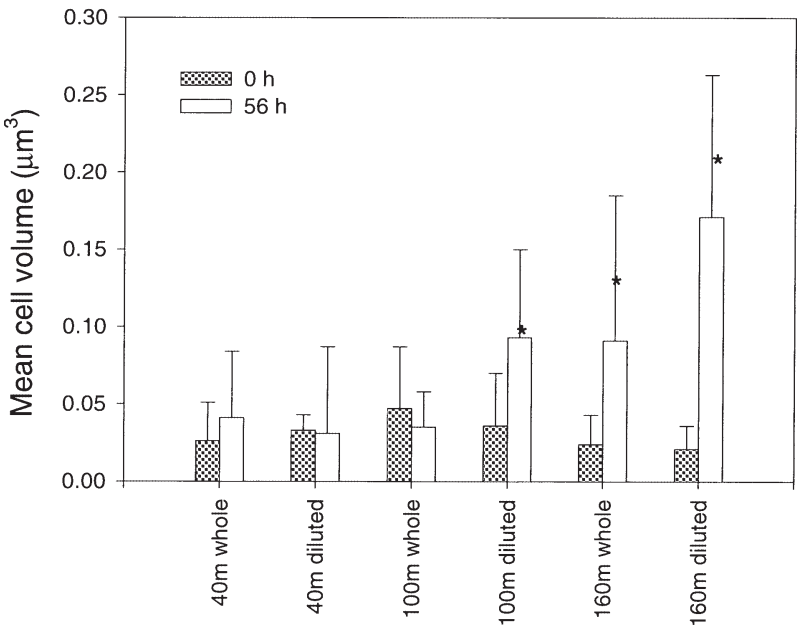

Fig. 10. Changes in mean bacterial cell volumes before and after incubation of seawater samples for $56 \mathrm{~h}$. Vertical lines represent 1 standard deviation. *Significant differences within a pair of samples (ANOVA, $\mathrm{p}<0.05$ )

It is not simple to compare bacterial growth rates among studies, due not only to temporal and spatial variability in bacterial growth rates, but also to the differences in methods employed, with each approach having advantages and disadvantages (Landry 1994). In the present study, 2 methods were employed to measure bacterial growth rates. In the first, using the $\mathrm{P} / \mathrm{B}$ ratio based on in situ measures (Table 2), depthintegrated mean bacterial growth rate was $0.1 \mathrm{~d}^{-1}$, precisely the value obtained by Rivkin \& Anderson (1997) in the Caribbean Sea and well within the range of bacterial growth rates reported for the open ocean (Ducklow 1999).

Meanwhile, mean bacterial growth rates obtained from incubation experiments were $0.58 \mathrm{~d}^{-1}$ (range 0.38 to $0.85 \mathrm{~d}^{-1}$ ) based on cell abundance and $0.75 \mathrm{~d}^{-1}$ (range 0.32 to $1.46 \mathrm{~d}^{-1}$ ) based on cell volume data (Table 3). In both cases, rates were significantly higher than in situ growth rates. The dilution technique provides an advantage in that it requires less manipulation of seawater, growth and removal rates are measured concurrently with enumeration of bacteria or incorporation of radioprecursors into bacterial macromolecules, and it has been widely used to estimate bacterial growth and removal rate in oceanic waters (Ducklow \& Hill 1985a,b, Ducklow et al. 1992, Landry et al. 1995).

It is not clear why in the present study there was a substantial discrepancy in estimating bacterial growth rates by these 2 approaches. One possible source of the difference is that since only 2 dilutions were used, as opposed to 5 to 10 dilutions as originally proposed by Landry \& Hassett (1982), computation of growth and bacterivory rates might have been affected. Another 
potential complication is that DOM might have been introduced into the diluted water during filtration, either by cell breakage or from contamination in the filtering system. We took care to minimize the introduction of DOM by adopting a standard protocol of cleaning and using gravity filtration to minimize cell breakage. It is not possible, however, to evaluate the possibility of any contamination or release of DOM because DOM measurements were not made before and after filtration. Using an approach similar to ours, however, Carlson \& Ducklow (1996) observed no significant 'before-after' difference in DOM concentrations.

The relatively low salinity water introduced during the sampling period was from the Amazon River, translated into the study area in rings spawned from the North Brazil Current (Kelly et al. 2000), a phenomenon recognized for decades (Steven \& Brooks 1972, Borstad 1982a,b). Recent studies, including remote sensing (Muller-Karger 1988), numerical models (Fratantoni et al. 1995), and tracking of the water's ${ }^{228} \mathrm{Ra} /{ }^{226} \mathrm{Ra}$ ratio (Moore et al. 1986, Moore \& Todd 1993), suggest that the low salinity pools introduced to Barbados are mostly from the Amazon River mixing zone. It takes approximately $100 \mathrm{~d}$ or even more for the Amazon water to travel in residuals of North Brazil Currents to Barbados (Kelly et al. 2000). Elevated concentrations of nutrients and pigments in the Amazon River discharge (i.e. $>1$ order of magnitude greater than the ambient concentration) occur close to the plume or to the northwest part of the Caribbean Sea far from Barbados (Muller-Karger 1988, Muller-Karger et al. 1989). The long transitional time, in concert with stripping of labile nutrients during transport, may account for there being no apparent change in planktonic biomass and bacterial production in the study area when the low salinity water arrived.

In summary, there existed spatial and temporal variation of phytoplankton biomass and bacterioplankton biomass, production, and growth in the euphotic layer during a month-long period of study near Barbados. Temporal variation of these measures, however, was not associated with an input of low-salinity discharge from the Amazon River. Bacterial biomass and production were coupled tightly or with slight time lags to phytoplankton biomass. Analysis of bottom-up and top-down process studies suggested that predation on bacteria exerts more influence on bacterioplankton dynamics than does control by resource supply.

Acknowledgements. We thank David Burdige, Hugh Ducklow, David Karl, Arnoldo Valle-Levinson and 2 anonymous reviewers for their constructive comments on earlier versions of this manuscript. We are grateful to Peter Kelly at MSRC SUNY Stony Brook and Claire Paris at RSMAS/MBF University of Miami for providing hydrographic data. We also thank
Curtis Hickman, Stephanie East, Teresa Rotunno, Graham Allen, and the captain and crew of the RV 'Seward Johnson' for their excellent assistance at sea and in the lab.

\section{LITERATURE CITED}

Azam F, Fenchel T, Field JG, Gray JS, Meyer-Reil LA, Thingstad F (1983) The ecological role of water-column microbes in the sea. Mar Ecol Prog Ser 10:257-263

Billen G, Joiris C, Wijnant J, Gillain G (1980) Concentration and microbiological utilization of small organic molecules in the Scheldt estuary, the Belgian coastal zone of the North Sea and the English Channel. Estuar Coast Mar Sci 11:279-294

Billen G, Servais P, Becquevort S (1990) Dynamics of bacterioplankton in oligotrophic and eutrophic aquatic environments: bottom-up or top-down control? Hydrobiologia 207:37-42

Borstad GA (1982a) The influence of the meandering Guiana Current and Amazon River discharge on surface salinity near Barbados. J Mar Res 40:421-452

Borstad GA (1982b) The influence of the meandering Guiana Current on surface conditions near Barbados - temporal variations of Trichodesmium (Cyanophyta) and other plankton. J Mar Res 40:435-452

Burney CM, Davis PG, Johnson KM, Sieburth JMcN (1982) Diel relationships of microbial trophic groups and in situ dissolved carbohydrate dynamics in the Caribbean Sea. Mar Biol 67:311-322

Carlson CA, Ducklow HW (1996) Growth of bacterioplankton and consumption of dissolved organic carbon in the Sargasso Sea. Aquat Microb Ecol 10:69-85

Cho BC, Azam F (1988) Major role of bacteria in biogeochemical fluxes in the ocean's interior. Nature 332:441-443

Cooper S (1991) Bacterial growth and division. Academic Press, New York

del Giorgio PA, Cole JJ, Cimbleris A (1997) Respiration rates in bacteria exceed phytoplankton production in unproductive aquatic systems. Nature 385:148-151

Ducklow HW (1983) Production and fate of bacteria in the oceans. BioScience 33:494-501

Ducklow HW (1992) Factors regulating bottom-up control of bacteria biomass in open ocean plankton communities. Arch Hydrobiol Beih Ergeb Limnol 37:207-217

Ducklow HW (1999) The bacterial component of the oceanic euphotic zone. FEMS Microbiol Ecol 30:1-10

Ducklow HW, Carlson CA (1992) Oceanic bacterial production. In: Marshall KC (ed) Advances in microbial ecology. Plenum Press, New York, p 113-181

Ducklow HW, Hill SM (1985a) The growth of heterotrophic bacteria in the surface waters of warm core rings. Limnol Oceanogr 30:239-259

Ducklow HW, Hill SM (1985b) Tritiated thymidine incorporation and the growth of heterotrophic bacteria in warm core rings. Limnol Oceanogr 30:260-272

Ducklow HW, Kirchman DL, Quinby HL (1992) Bacterioplankton cell growth and macromolecular synthesis in seawater cultures during the north Atlantic spring phytoplankton bloom, May, 1989. Microb Ecol 24:125-144

Ferguson RL, Rublee P (1976) Contribution of bacteria to standing crop of coastal plankton. Limnol Oceanogr 22: 141-145

Fratantoni DM, Johns WE, Townsend TL (1995) Rings of the North Brazil Current: their structure and behavior inferred from observations and a numerical simulation. J Geophys Res 100:10633-10654 
Fuhrman JA (1992) Bacterioplankton roles in cycling of organic matter: the microbial food web. In: Falkowski PG, Woodhead AD (eds) Primary productivity and biogeochemical cycles in the sea. Plenum Press, New York, p 361-383

Fuhrman JA (1999) Marine viruses and their biogeochemical and ecological effects. Nature 399:541-548

Fuhrman JA, Sleeter TD, Carlson CA, Proctor LM (1989) Dominance of bacterial biomass in the Sargasso Sea and its ecological implications. Mar Ecol Prog Ser 57:207-217

Kelly PS, Lwiza KMM, Cowen RK, Goni GJ (2000) Low-salinity pools at Barbados, West Indies: their origin, frequency and variability. J Geophys Res 105:19699-19708

Landry MR (1994) Methods and controls for measuring the grazing impact of planktonic protists. Mar Microb Food Webs 8:37-57

Landry MR, Hassett RP (1982) Estimating the grazing impact of marine micro-zooplankton. Mar Biol 67:283-288

Landry MR, Kirshstein J, Constantinou J (1995) A refined dilution technique for measuring the community grazing impact of microzooplankton, with experimental tests in the central equatorial Pacific. Mar Ecol Prog Ser 120:53-63

Lee S, Fuhrman JA (1987) Relationship between biovolume and biomass of naturally derived marine bacterioplankton. Appl Environ Microbiol 53:1298-1303

Moore WS, Todd JF (1993) Radium isotopes in the Orinoco estuary and eastern Caribbean. J Geophys Res 223: 407-411

Moore WS, Sarmiento JL, Key RM (1986) Tracing the Amazon component of surface Atlantic water using ${ }^{228} \mathrm{Ra}$, salinity and silica. J Geophys Res 91:2574-2580

Editorial responsibility: David Karl,

Honolulu, Hawaii, USA
Morita RY (1997) Bacteria in oligotrophic environments. Chapman \& Hall, New York

Muller-Karger FE (1988) The dispersal of the Amazon's water. Nature 333:56-59

Muller-Karger FE, McClain CR, Fisher TR, Esaias WE, Varela $R$ (1989) Pigment distribution in the Caribbean Sea: observations from space. Prog Oceanogr 23:23-64

Parsons TR, Maita Y, Lalli CM (1992) A manual of chemical and biological methods for seawater analysis. Pergamon Press, New York

Porter KG, Feig Y (1980) The use of DAPI for identifying and counting aquatic microflora. Limnol Oceanogr 25:943-948

Rivkin RB, Anderson MR (1997) Inorganic nutrient limitation of oceanic bacterioplankton. Limnol Oceanogr 42:730-740

Sanders RW, Caron DA, Berninger UG (1992) Relationships between bacteria and heterotrophic nanoplankton in marine and fresh waters: an inter-ecosystem comparison. Mar Ecol Prog Ser 86:1-14

Shiah FK, Ducklow HW (1994) Temperature and substrate regulation of bacterial abundance, production and specific growth rate in Chesapeake Bay, USA. Mar Ecol Prog Ser 103:297-308

Steven DM, Brooks AL (1972) Identification of Amazon River water at Barbados, W. Indies, by salinity and silicate measurements. Mar Biol 14:343-348

Steven DM, Glombitza R (1972) Oscillatory variation of a phytoplankton population in a tropical ocean. Nature 237: 105-107

Wright RT, Coffin RB (1984) Measuring microzooplankton grazing on planktonic marine bacteria and its impact on bacterial production. Microb Ecol 10:137-149

Submitted: May 11, 2000; Accepted: April 13, 2001

Proofs received from author(s): July 25, 2001 